\author{
$\overline{\text { 原 著 }}$ \\ 胎児発育判定と出生時新生児体重の推定 \\ 岸英子 \\ 弘前大学医療技術短期大学部 - 専攻科助産学特別専攻

\section{Fetal Growth Estimation and Presumption of the Newborn Birthweigth} \\ Eiko Kishi \\ School of Allied Medical Sciences, Hirosaki University \\ Department of Midwifery
}

\begin{abstract}
Development of the newborn infant is estimated by gestational ages, liveborn birthweight and stature, another measurement and maturation's sign.

But for 9 months the intrauterine fetal to be grows unseen. Maturation of fetal infant is prominently associated with gestational ages. Only has it been recognized that in a given infant the degree of maturation of any one organ system could be relatively accelerated or delayed.

Obstetrics made recently remarkable progress for the medical electronics. However, fetal growth estimation and presumption of the newborn birthweight are difficult. Intrauterine growth retardation and small-for-dates infant that must be prevent. Maternal and child health care is very important to midwife.

This time, I was presumption of the newborn birthweight by next method.

1 Biporietal diameters of the fetus head by diagnostic ultrasound (electronic scan)

$\mathrm{Y}=900 \mathrm{X}-5,200$

2 Jacobson's formula $\quad \mathrm{W}=(\mathrm{F}-12) \times 155$

3 Araki's formula $\quad \mathrm{W}=(124.4 \mathrm{~F})-985.0$

4 an overall presumption by midwife students

Consequently, an overall presumption was nearly newborn birthweight, so that presumption of the newborn birthweight must be estimated by gestational ages, developmental curve of fundus uteri, biporietal diameters of the fetus head and anothers.
\end{abstract}

\section{I はじめに}

胎児の発育は，母体・胎児・胎盤の代謝相関 により調整されており，子宮内環境の恒常性の 変化は胎児の発育に強く影響すると考えられる。 子宮内胎児発育遅延 (IUGR $=$ Intra Uterine Growth Retardation) と出生後の SFD (Small for date's infant）は児の予後に影響が大きいの で妊婦管理上, 新生児管理上, しばしば問題と
なるところである。

新生児の発育は, 在胎期間, 出生時体重・身 長, 身体各部の計測, 成熟徵候の観察などによ ク総合的に判定される。しかし，子宮内胎児の 発育判定の場合には，直接胎児を計測したり， 成熟徵候を観察することはできない。

児体重の推定法についても諸家により報告さ れている。主なものをまとめると, 胎児発育判 
I 妊婦の外計測法

1 子宮底長

2 腹 囲

3 体 重

4 身 長

II 超音波診断法

1 妊娠子宮容積（子宮体部長、子宮厚）

2 胎児計測（胎のj、頭殿部長、児頭大横径、児胸郭横径、他）

III 羊水検査法

1 羊水中 creatinine 值

2 羊水中オレンジ線胞出現率

3 羊水中 bilirubine 值

4 羊水中 lecithin 濃度

IV 胎児胎盤機能検查法

1 尿中 estriol 值 $\left(\mathrm{E}_{3}\right)$

2 尿中 human placental lactogen ( h P L)

3 血清 heat stable alcaline phosphatase (H S A P)

4 血清 cystin aminopeptidase ( C A P )

5 血清 leucin aminopeptidase ( L A P)

V X 線検查法

VI その他

表 2 新生児体重の推定方法

I 在胎期間からの推定

1 船川の在胎週数別出生時体重基準 $\mathrm{SD} \pm 360 \mathrm{~g}$

2 Lubchenco の在胎週数別子宮内発育基準

3 日本産婦人科学会胎児臨床問題委員会の曲線 $3 / 2 \mathrm{SD} \pm 600 \mathrm{~g}$

4 神の体重概算法 $\left(G \times 3 \times M^{3}\right)$

5 Stratz 法、その他

II 外計測法による子宮底長からの推定

1 荒木 $\mathrm{W}$ (児体重) $=124.4 \mathrm{~F}$ (子宮底長 $)-985.0$

2 Jacobson $\mathrm{W}$ (児体重 $)=\{\mathrm{F}$ (子宮底長 $)-12\} \times 155$

3 鈴村 $G($ 児体重 $)=357.1 X$ (子宮底長 $)-6394.5 \quad r=+0.51$

4 町田 $\mathrm{Y}$ (児体重) $=63.24 \mathrm{X}$ (子宮底長 $)+1199.92 \mathrm{r}=+0.23$

5 梅沢、岩崎 $r=+0.66$

6 小林 $r=+0.62$

III 超音派断層法による児頭大横径計測值からの推定

1 日本産婦人科学会胎児臨床問題委員会

$$
\mathrm{Y}=900 \mathrm{X}-5200 \quad \mathrm{r}=+0.66
$$

2 竹内、竹村 $\mathrm{Y}=838.3 \mathrm{X}-4,411 \mathrm{Y}=900 \mathrm{X}-5,200 \mathrm{r}=+0.66$

3 町田 $\mathrm{Y}=673.75 \mathrm{X}-3,027.05 \quad \mathrm{r}=+0.82 \mathrm{SD}+400 \mathrm{~g}$

4 須田 $\quad \mathrm{Y}=717.06 \mathrm{X}-2.472 \quad \mathrm{r}=+0.545$

注 $(\mathrm{Y}=$ 児体重、 $\mathrm{X}=$ 児頭大横径 $)$ 
定法は表 1, 新生児体重の推定方法は表 2 の おりである。現在では，超音波断層法の導入に より胎児情報を把握できるようになり，児頭大 横径や胸郭横径等から児体重を換算し好成績を 得るようになった。

しかしながら，子宮内羊水中で生存発育を続 けている胎児の発育を的確に判定したり，正確 に児体重を推定できる単一の方法は ME 機器 の発達した今日においても見当らない。

そこで，児体重の推定方法について，4つの 方法を比較し，誤差範囲について検討したので 報告する。

\section{II 研究目的}

妊婦の健康診查を実施したら，胎児の発育判 定をし，正常か異常か判断し，それに伴って妊 婦を管理しなければならない。又，産婦管理に おいては, 助産計画を立案し，流児共に安全で 安楽な分婏を保障しなければならない。

助産計画立案時には, 出生時体重と新生児成 熟度を推定することは重要なことであり, IUG-
$\mathrm{R}$ で SFD が疑われる場合には, 出生後の新生 児管理の準備をして分娩に対応する必要がある。 可能な限り的確に胎児発育と出生時体重を推定 し，妊産婦管理，新生児管理に役立てるために この研究を行った。

\section{III 研究対象および方法}

対象は昭和 49 年から昭和 56 年までの間に, 私どもの指導下にあった学生が管理した事例で, 在胎週数が明確で, 重症の妊娠合併症を有しな い, 在胎 32 週以降に超音波断層法により児頭大 横径を計測し, 在胎 36 42 週で出生した 306 例 (男児 148 例, 女児 158 例, 初産婦から出生し た児 138 例，経産婦から出生した児 168 例）で ある。

方法は，(1)超音波断層法による児頭大横径計 測值からの推定体重, (2)子宮底長計測值からの 推定体重一一Jacobson 換算式による推定体重, 荒木換算式による推定体重，(3)学生による推定 体重，の 4 つの方法を出生時の実測体重と比較 検討した。

表 3 助産婦学生による新生児体重推定法

1 妊婦外計測法による子宫底長加らの推定

荒木式 $\quad W($ 児体重 $)=124.4 \mathrm{~F}$ (子宮底長 $)-985.0$

Jacobson 式 $W($ 児体重 $)=\{F($ 子宮底長 $)-12\} \times 155$

2 外計測法による子宮底長と腹囲からの推定

3 超音派断層法による児頭大横径からの推定

日本産婦人科学会胎児臨床問題委員会の換算式

$\mathrm{Y}($ 児体重 $)=900 X$ (児頭大横径 $)-5,200$

4 在胎期間 (船川の曲線) と Pregnogram（北大式）から推定

5 腹部触診による胎児触知感から推定

6 妊娠中の母体体重増加量、母体身長

7 経産婦の場合は、既往好娠時の子宮底長と児体重

8 合併症、その他

上記事項を総合し、指導者の判断と併せて推定

推定体重の算出方法は以下による.

(1) 児頭大横径計測值からの推定体重は日本 産科婦人科学会胎児臨床問題委員会提唱による 換算式から算出した。

$\mathrm{Y}($ 児体重 $)=900 \mathrm{X}($ 大横径 $\mathrm{cm})-5,200$

児頭大横径測定週数と出生時在胎週数の一致 しないものについては $y($ 大横径 $)=0.23 \mathrm{~W}$ (在胎週数 $)-0.5$ により修正し児体重を算出した。

(2) 妊婦の外計測法による子宮底長測定値 (安藤式の測定による) からの推定体重は, Jacobson 換算式と荒木換算式から算出した。 


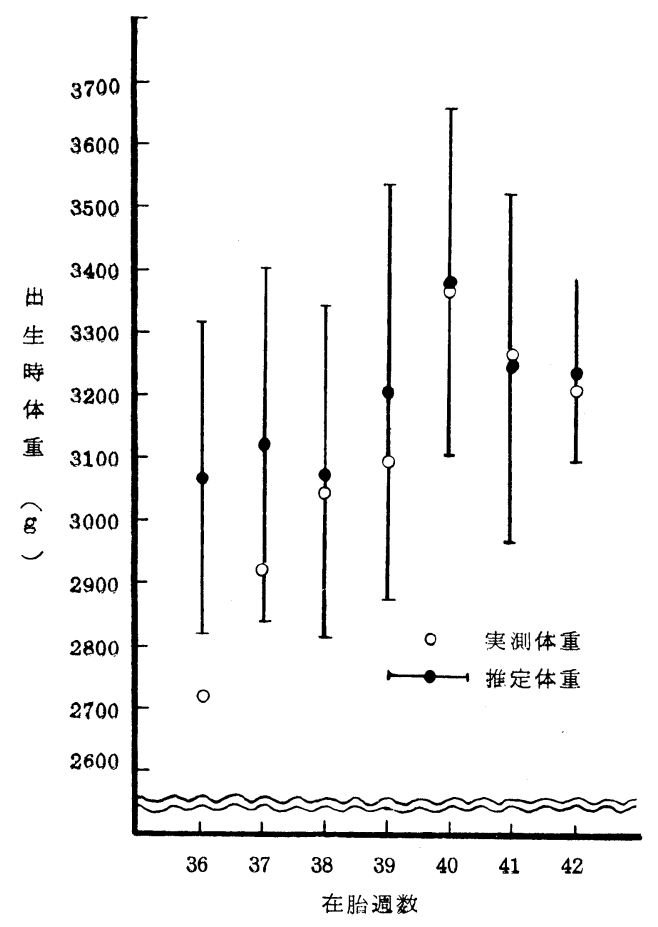

児頭大横径からの推定体重

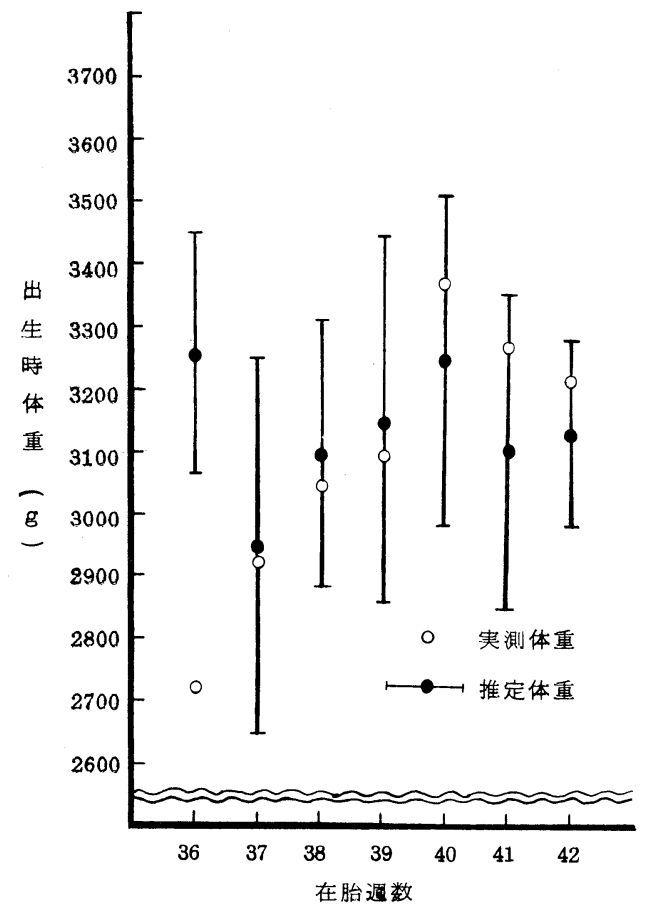

荒木式に上る推定体重

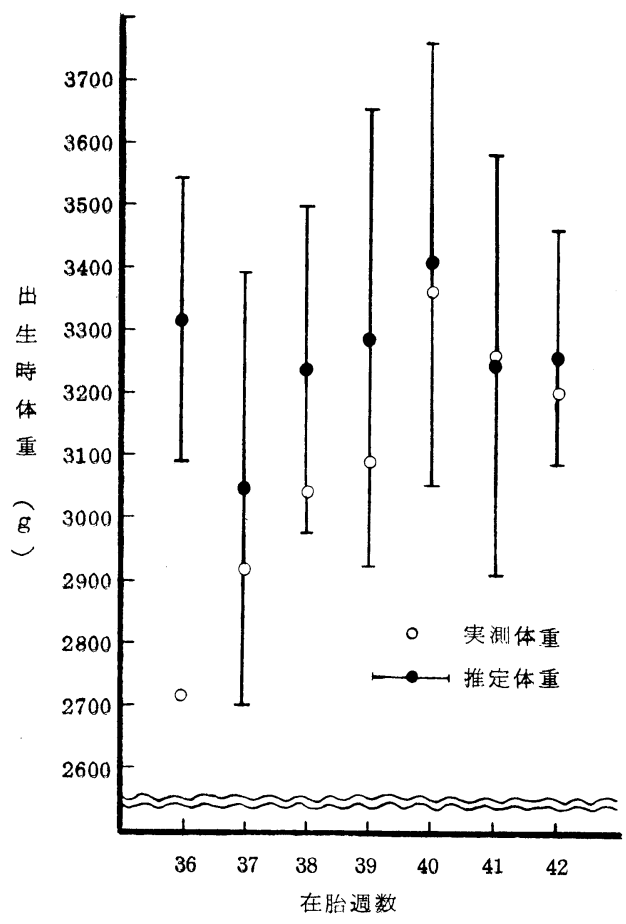

ヤコブソン式による推定体重

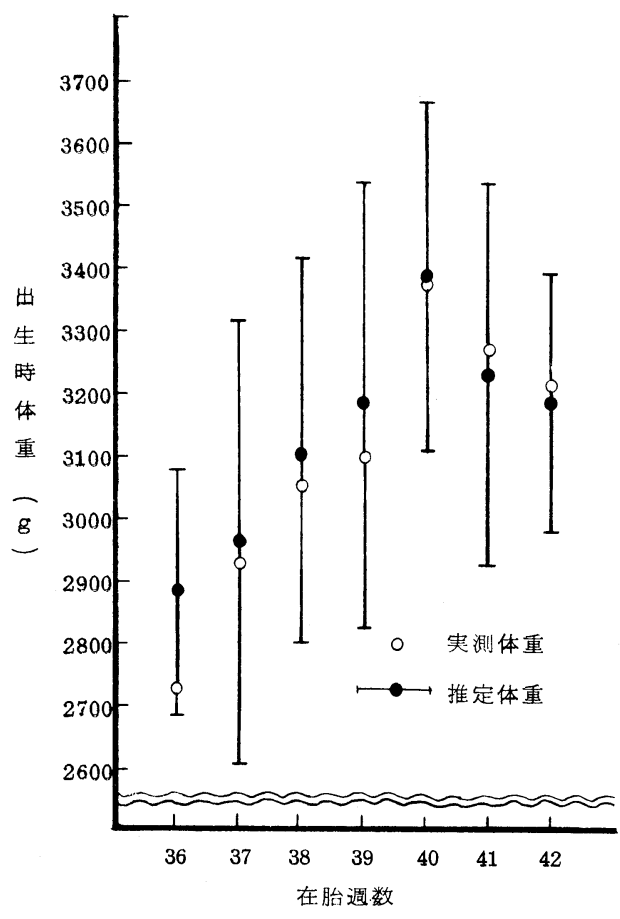

学生に上る推定体重

図 I 在胎週数別 - 出生時体重と推定体重比較 
Jacobson

$\mathrm{W}($ 児体重 $)=\{\mathrm{F}($ 子宮底長 $)-12\} \times 155$

荒 木

$\mathrm{W}$ (児体重 $)=124.4 \mathrm{~F}$ (子宮底長 $)-985.0$

(3) 学生の推定した新生児体重は表 3 に示す とおりで，総合判定して算出した児体重である.

\section{IV 研究成績}

1. 在胎週数別, 子宮底長 - 腹囲 - 児頭大横 径, 出生時体重

表 4 に在胎週数別の妊婦外計測法による子宮 底長平均值，腹囲平均值，超音波断層法による 児頭大横径平均值, 出生時の新生児実測体重を
示した. 尚, 母体体重増加量は在胎 36〜 42 週の 平均值が $10.3 \mathrm{~kg}, \mathrm{SD} \pm 4.2 \mathrm{~kg}$, 母体身長は $155.4 \mathrm{~cm}, \mathrm{SD} \pm 6.1 \mathrm{~cm}$ であった。

腹囲を除いた子宮底長, 児頭大横径, 出生時 体重は当然のことながら在胎週数に比例してい る. 在胎 41 週, 42 週では在胎週数よりも子宫底 長および児頭大横径に比例している。

在胎 36 週の子宮底長が高値に出たのは, 例数 が少ない上, 妊娠中の母体体重増加が著明で腹 壁の厚い妊婦が 12 例中 6 例含まれていたため 胎児発育と子宮底長計測值が比例しなかったも のと思われる。

表 4 在胎週数別子宮底長 - 腹囲 - 児頭大横径 - 出生時体重の平均値

\begin{tabular}{|c|c|c|c|c|c|}
\hline 在 胎 週 数 & 例 & 子宮底長 & 腹 & 児頭大横径 & 出生時体重 \\
\hline 週 & 例 & $\mathrm{cm}$ & $\mathrm{cm}$ & $\mathrm{mm}$ & $g$ \\
\hline 36 & 12 & 34.4 & 94.3 & 91.9 & $2729.3 \pm 267.6$ \\
\hline 37 & 30 & 31.6 & 92.3 & 92.5 & $2924.5 \pm 382.7$ \\
\hline 38 & 46 & 32.8 & 91.7 & 92.0 & $3041.9 \pm 427.6$ \\
\hline 39 & 68 & 33.2 & 95.3 & 93.5 & $3090.4 \pm 378.4$ \\
\hline 40 & 74 & 34.2 & 93.8 & 95.2 & $3365.9 \pm 362.7$ \\
\hline 41 & 66 & 31.7 & 92.0 & 93.9 & $3262.5 \pm 388.3$ \\
\hline 42 & 10 & 33.0 & 90.9 & 93.8 & $3208.0 \pm 224.7$ \\
\hline
\end{tabular}

2. 在胎週数別, 出生時体重と推定体重の比 較

図 1 は在胎週数別出生時の実測体重と推定体 重を比較したものである。

(1) 児頭大横径からの推定体重は在胎 38 週 以降は近似值を示しており,特に 40 週以降の平 均值は実測值に近かった. SD (標準偏差) 144.0 土 $329.7 \mathrm{~g}$ と在胎週数によりばらつき がみられたが, 36 週を除いて実測体重は標準偏 差值内にあった。

(2) Jacobson 式による推定体重は 40 週以降 は近似值を示したが, 39 週以前においては実測 体重との間に差がみられた. $\mathrm{SD} \pm 176.7$ - 367.9 $\mathrm{g}$ であり, 在胎週数によるばらつきは児頭大横 径からの推定体重以上であり，36 週を除いて実 測体重は標準偏差值内にあった。

(3) 荒木式による推定体重は 37～39 週まで 近似值を示したが, 40 週以降は実測值との間に

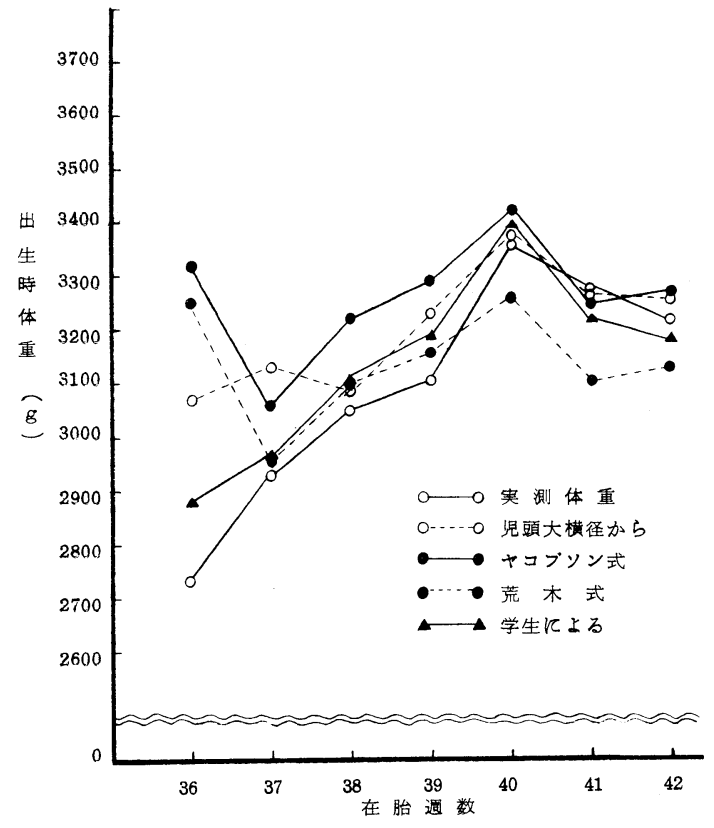

図 2 出生時体重と推定体重の平均値比較 
差がみられた。 $\mathrm{SD} \pm 142.1 〜 \pm 300.3 \mathrm{~g}$ であり， 在胎週数によるばらつきは上記 2 法に比較して 少ない. 36 週を除いて実測体重は標準偏差值内 にあった。

(4) 学生による推定体重は 37〜 42 週まで実 測体重との間の差が少なく近似值を示している. $\mathrm{SD} \pm 195.1$ 365.1 g であり, 在胎週数によるば らつきはあるが, 36 週以降すべて実測体重は推
定体重の標準偏差值内にあった。

図 2 は出生時体重（実測体重）と推定体重の 平均值を比較したものである。平均值比較によ る誤差が最大であったものは，36 週で+594.5 g, 37 週で+198.2 g, 38 週で+199.7 g, 39 週 で+196.6 g, 40 週で-119.5 g, 41 週で-163.4 $\mathrm{g}, 42$ 週でー $88.2 \mathrm{~g}$ であった。全体的には学生 による推定体重が実測体重に最も近かった。

\section{表 5 在胎週数別出生時体重（実測体重）と推定体重比較}

\begin{tabular}{|c|c|c|c|c|c|c|c|c|c|c|}
\hline \multirow{2}{*}{ 在胎週数 } & 例 & \multirow{2}{*}{ 出生時体重 } & \multicolumn{2}{|c|}{ 大横径から } & \multicolumn{2}{|c|}{ ヤコブソン式 } & \multicolumn{2}{|c|}{ 荒 木 式 } & \multicolumn{2}{|c|}{ 学生による } \\
\hline & 数 & & 推定体重 & 詥 & 推定体重 & 䛊 & 推定体重 & 䛊 & 推定体重 & 詰 \\
\hline 36 & 12 & 2729.3 & 3070.0 & +340.7 & 3323.8 & +594.5 & 3254.5 & +525.2 & 2883.3 & +154.0 \\
\hline 37 & 30 & 2924.5 & 3122.7 & +198.2 & 3053.5 & +129.0 & 2941.4 & +16.9 & 2963.3 & +38.8 \\
\hline 38 & 46 & 3041.9 & 3076.1 & +34.2 & 3241.6 & +199.7 & 3098.1 & +56.2 & 3100.0 & +58.1 \\
\hline 39 & 68 & 3090.4 & 3210.9 & +120.5 & 3287.0 & +196.6 & 3145.4 & +55.0 & 3180.3 & +89.9 \\
\hline 40 & 74 & 3365.9 & 3367.0 & +1.1 & 3412.1 & +46.2 & 3246.4 & -119.5 & 3385.1 & +19.2 \\
\hline 41 & 66 & 3262.5 & 3251.8 & -10.7 & 3248.0 & -14.5 & 3099.1 & -163.4 & 3222.7 & -39.8 \\
\hline 42 & 10 & 3208.0 & 3242.0 & +34.0 & 3255.2 & +47.2 & 3119.8 & -88.2 & 3180.0 & -28.0 \\
\hline
\end{tabular}

(単位 $=g$ )

表 6 出生時体重（実測体重）に対する推定体重の誤差

\begin{tabular}{|c|c|c|c|c|}
\hline 誤 差 推定方法 & 大横径から推定 & ヤコブソン式 & 荒木 & 学生による推定 \\
\hline 最 小 䛊 差 & 8 & 8 & 5 & 0 \\
\hline 平 均 誤 差 & 323.5 & 316.7 & 283.9 & 132.1 \\
\hline 最 大 誤 差 & 1234 & 1378 & 1151 & 652 \\
\hline 標 準 偏 差 & +563.5 & +569.6 & +519.9 & +242.3 \\
\hline
\end{tabular}

(単位 $=g$ )

3 . 在胎週数別, 出生時体重と推定体重の誤 差

表 5 は出生時体重（実測体重）と推定体重の 平均値の誤差を示したものである。表 6 は両者 間の最小誤差, 平均誤差, 最大誤差, 標準偏差 を示したものである。

(1) 児頭大横径からの推定体重平均值の誤差 は+1.1 g〜+340.7 gの間にあり，40週では+ $1.1 \mathrm{~g}, 41$ 週では- $10.7 \mathrm{~g}, 42$ 週では+34.0 g, 38 週では+ $34.2 \mathrm{~g}$ と好成績を示している. 個別 に比較すると最小誤差は $8 \mathrm{~g}$, 最大誤差 1,234 $\mathrm{g}$, 平均誤差 $323.5 \mathrm{~g}$, 標準偏差 $563.5 \mathrm{~g}$ であっ た。

(2) Jacobson 式による推定体重平均値の䛊 差はー $14.5 \mathrm{~g} \sim+594.5 \mathrm{~g}$ の間にあり, 40 週, 41
週，42 週と好成績を示している. 個別に比較す ると最小誤差は $8 \mathrm{~g}$, 最大誤差 $1,378 \mathrm{~g}$, 平均誤 差 $316.7 \mathrm{~g}$ ，標準偏差土569.6 g であった。

(3) 荒木式によると推定体重平均値の誤差 は+16.9 g〜 + 525.2 g の間にあり，37 週，38 週, 39 週と好成績を示し, 40 週以降は実測値よ ク低い数值を示している。個別に比較すると最 小誤差は $5 \mathrm{~g}$, 最大誤差 $1,151 \mathrm{~g}$, 平均誤差 283.9 $\mathrm{g}$, 標準偏差土519.9 g であり，上記 2 法より誤 差が少ない.

(4) 学生による推定体重平均値の誤差は一 $19.2 \mathrm{~g} \sim+154.0 \mathrm{~g}$ の間にあり，37 週以降の平 均誤差は $100 \mathrm{~g}$ 以下であった。個別に比較する と最小誤差は $0 \mathrm{~g}$ で 306 例中 2 例, 最大誤差 $650 \mathrm{~g}$, 平均誤差 $132.1 \mathrm{~g}$, 標準偏差土242.3 g で 
あり，他の 3 法に比し最も誤差が少なかった。

4. 出生時体重に対する推定体重の誤差分布 表 7 は出生時体重（実測体重）に対する推定 体重の誤差分布を示したものである。

今回の結果では, 児頭大横径からの推定体重, Jacobson 式による推定体重の 2 法ともに䛊差 のばらつきが大きい. $501 \mathrm{~g}$ 以上の誤差を示し
たものが $20.3 \%$ を占めており，約 $1 / 5$ に相当 する。

荒木式による推定体重では $300 \mathrm{~g}$ 以内の誤差 を示したものが $62.8 \%, 501 \mathrm{~g}$ 以上の誤差は $13.7 \%$ であった。

学生による推定体重では $100 \mathrm{~g}$ 以内の誤差が $50.3 \%, 200 \mathrm{~g}$ 以内 $77.8 \%, 300 \mathrm{~g}$ 以内 $89.6 \%$ であり， $501 \mathrm{~g}$ 以上の誤差は $0.6 \%$ であった。

表 7 出生時体重（実測体重）に対する推定体重の誤差分布（百分率）

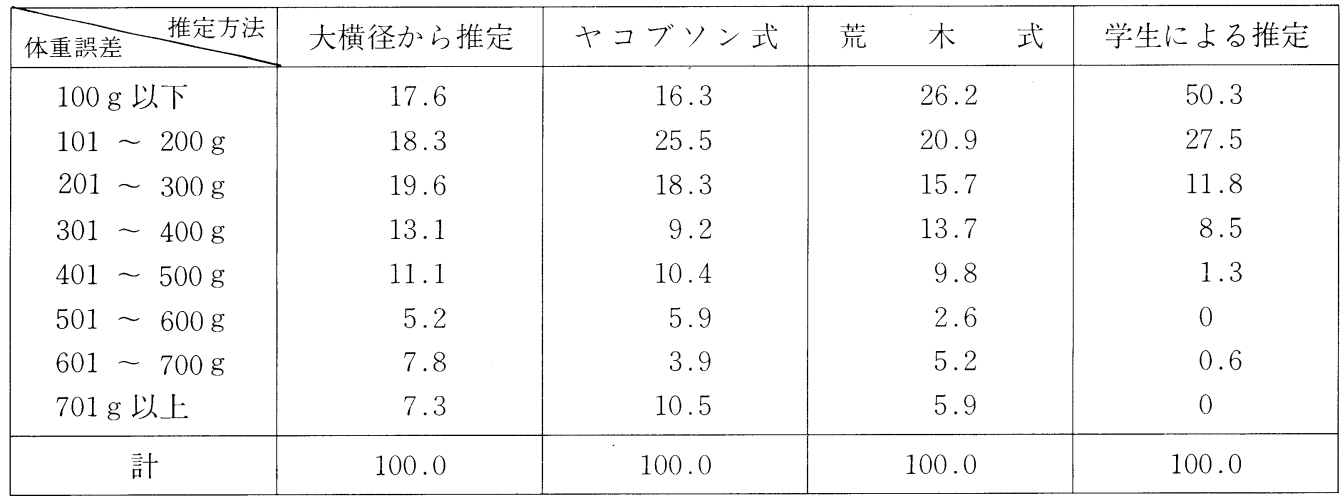

\section{$\mathrm{V}$ 考 察}

出生時の新生児実測体重に対する超音波断層 法による児頭大横径計測值からの推定体重, 妊 婦外計測法による子宮底長測定值からの推定体 重 (Jacobson 式, 荒木式), 学生が総合判定し た推定体重を比較検討した。

その結果, 在胎 36 週の出生時体重と推定体重 の平均值比較においては, 児頭大横径からの推 定体重では+340.7 g, Jacobson 式からの推定 体重では+594.5g, 荒木式からの推定体重で は+525.2 g, 学生による推定体重+154.0 g の 誤差を認めた。その理由は, 例数が少なく, 又, 腹壁が厚かったため子宮底長測定值に影響した ものと思われる。

従って, pre-termの胎児発育判定時には子宮 底長だけで判定せず，在胎期間からの判定法と 腹部触診所見を考慮し判定する必要があると考 之る。

在胎 37〜41 週の termにおいては pre-term, post-term に比し誤差が少なく, 在胎期間から 推定しても，子宮底長測定值加推定しても，
児頭大横径計測値から推定しても，実測体重に 近い数值を得ることができた。全体として，児 頭大横径からの推定体重と学生による総合的な 推定が実測体重により近似值を示していた。 Jacobson 式からの推定体重では 40 週以降に近 似值を示し, 荒木式からの推定体重では 39 週以 前に近似值を示した。

しかし，それぞれの方法の個々の推定体重を みた場合, 児頭大横径からの推定体重, Jacobson 式による推定体重, 荒木式による推定体重 ともに標準偏差が約 $\pm 520 \mathrm{~g} \sim 570 \mathrm{~g}$ と大きい. とくに児頭大横径からの推定, Jacobson 式から の推定では $501 \mathrm{~g}$ 以上の誤差を認めたものが $20.3 \%$ に及んでいる. 児体重推定が $500 \mathrm{~g}$ 以上 の差がある場合には IUGR の診断や SFD の予 測診断はむずかしい.ただし，今回調査した児 頭大横径計測值は, 測定週数と出生時在胎週数 の一致しなかったものについては修正值を用い た. 修正した数值から児体重を推定したため誤 差が大きく出た可能性も考えられる.

尚，児頭大横径から胎児発育を判定するには 
2 回以上の計測值比較がよいとされ，1 週平均 増加 $2.3 \mathrm{~mm}$ であり， $1.7 \mathrm{~mm}$ 以下の場合は IUGR を疑う必要があるとし，胎児臨床問題委 員会では $90 \mathrm{~mm}$ 以上の時は児体重はほぼ $2,500 \mathrm{~g}$ 以上に達していると提唱しているが, 報告者によって見解を異にしている.

助産婦学生の推定した児体重が出生時体重 (実測体重)に最も近く, 約 $90 \%$ が $300 \mathrm{~g}$ 以内 の誤差範囲にあった。このことは，単一方法の 推定だけによらず，多くのデー夕を総合して判 定した結果だと思われる。

\section{VI おわりに}

新生児成熟度の判定にも多くの問題が残され ている今日，胎児発育・成熟度を判定すること は容易なことではない，的確に出生時の新生児 体重を推定することはむずかしいことであるが, 単一のデー夕から胎児発育判定や出生時体重の 推定をするのではなく, 在胎週数始め, 正確な 妊婦の外計測, 超音波所見, 腹部触診所見, そ の他胎児発育に影響を及ぼす諸因子を客観的に 観察し, デー夕を総合判定する必要がある。

今後ますます超音波断層法による胎児発育判 定がなされていくことと思われるが, 決して助 産婦による健康診查や胎児発育判定が不必要に なるということではない。まして，産婦管理上 助産婦の役割は極好大きい。今回の調査結果 を学生指導や妊産婦の care, 新生児の care に 役立てたい.

\section{参考文献}

1）小林充尚：子宮内胎児発育遅延, 産婦人科の 実際，27 (2)，285 ， 1978.

2）坂元正一他：昭和 50 年度厚生省心身障害研 究胎児環境研究班研究報告書, 155 191

3）坂元正一：超音波診断法最近の進歩, 産婦人 科治療, 43 (1), 13 , 1981.

4) 坂元正一他：胎児医学, 111 131, 同 文書院, 1977 .

5）相良裕輔他：胎児発育遅延, 産科と婦人科, 45 (1), 22〜, 1978.

6）鈴村正勝：胎児成熟度判定, 産科と婦人科, 43 (4), 148 , 1976.
7）竹村 晃他：産婦人科領域における新しい超 音波診断の意義とその運用の実際, 産科と婦 人科, 44 (7), 10 , 1977.

8) 竹内久弥: 新しい超音波診断法とその将来, 産科と婦人科, 44 (7), 1 , 1977.

9）竹内久弥：胎児異常の超音波診断法, 産婦人 科治療, 43 (1), 40〜, 1981.

10）長谷川敏雄他：母子保健講座 4 , 母子保健管 理 (2 版), 96, 医学書院, 1981.

11）前田一雄他：妊娠末期への応用, 産科と婦人 科, 44 (7), 19 , 1977.

12）真柄正直著・室岡一改訂：最新産科学正常編 (第 18 版), 41 57, 文光堂, 1980 .

13）諸橋 㑆他：妊娠初期 - 中期における超音波 診断のこつとその限界, 産科と婦人科, 44 (7), 15〜, 1977. 